\title{
Climate Change and Its Lexicon: An Analytical and Critical View
}

\author{
José Maurício Domingues ${ }^{1}[$
}

Accepted: 5 October 2021

(c) The Author(s), under exclusive licence to Springer Science+Business Media, LLC, part of Springer Nature 2021

\begin{abstract}
Climate change is an overwhelming issue today, but sociology has yet to fully engage with its hermeneutical and political aspects. The article tackles this limitation and thus the lexicon of climate change, proposing an integrated framework that brings its principal concepts and notions together. In particular, it singles out hazard, risk and threat, vulnerability and resilience, adaptation, mitigation and precaution, Anthropocene and Capitalocene, nature and society. Although some authors have stressed the political aspects underlying these concepts and notions, and the IPCC itself has incipiently recognised this issue, the parameters of the debate remain conspicuously narrow. The article therefore proposes to engage it in direct and strong political terms, countering the partly successful operation of depoliticisation that such concepts and notions undergo. While the article concentrates on discursive aspects, it eventually points to the role of agents and power within the UN system concerning the articulation of this lexicon.
\end{abstract}

Keywords Anthropocene and Capitalocene - Climate change - Depoliticisation . IPCC $\cdot$ Adaptation · Mitigation and Precaution · Resilience $\cdot$ Risk $\cdot$ Vulnerability

\section{Introduction}

Climate change is an outstanding contemporary theme. Through the analysis of the lexicon employed by official international organisations and the research directly or indirectly related to them, this article intends to bring out its main discursive apparatus, outline its limitations, as well as identify possibilities and shifts it might demand. It provides an integrated framework that brings together its principal concepts and notions. As is common in the tradition of critical theory, the analysis initially proceeds from within concepts - thus, immanently—so as to bring out

José Maurício Domingues

jmdomingues@iesp.uerj.br

1 IESP-UERJ, Rua da Matriz 82, CEP 22260-100, Rio de Janeiro, RJ, Brazil 
blockages and potential avenues, and also eventually to point out how power relations are intertwined and underpinned in their production (Domingues, 2006). If some authors examined below have already stressed the political aspects underlying these concepts and notions - something even the IPCC has done -, and, in an incipient way, recognised this issue, the parameters of the debate are usually narrow. In particular, the issue of power has remained largely absent from the mainstream debate. The article thus proposes to take them on in direct and strong political terms, offering an approach based on political sociology, with an emphasis on the hermeneutical aspect of the imaginary of climate change (which is no less real) as well as on the organisations and institutions related to it. The article places agents and power centre-stage, thereby moving beyond the 'post-political' framework prevalent in the field of climate change (Brulle \& Dunlap, 2015, pp. 12-14, 17).

The discussion of climate change has been huge and has involved resources of great magnitude. It has generated its own lexicon. This is however articulated to other fields of specialisation, and has constituted an evolving area of the contemporary social imaginary, symbolically threaded by cognitive, evaluative, normative and expressive elements, which mediate our individual and collective relations with reality in its totality. The fields of specialisation that contribute to this symbolic (as well as practical) construction include the analysis of disasters and risks, as well as global public health (Domingues, 2021), with significant influence of and connection to international organisations. The United Nations (UN) stands out in this regard, promoting concepts that are shared in diverse areas (UN/ISDR, 2004), including the struggle against poverty, especially with regard to those in particular situations of 'risk' and 'vulnerability', in this case closely connected to the World Bank's discursive categories (Rodríguez Ortiz, 2014). This is also the case with the United Nations Framework Convention on Climate Change (UNFCCC) and its Intergovernmental Panel on Climate Change (IPCC). Discursively, the IPCC reports since 1990 are very relevant. The most recent version dates from 2014, and includes an annex/glossary of definitions, even if they are in fact quite vague and restricted (IPCC, 2014).

The lexicon of climate change allows us to see it precisely as a true practicalhermeneutic province of social life, fluid and with imprecise borders between science and politics. To deal critically with the subject, this article will summarize and refine what other authors have already partly accomplished, hence presenting a systematic perspective. All the concepts of this basic lexicon are polysemic and have gradually and partially included, even officially, social and political aspects that mitigate its previously more technocratic and neutral character, nevertheless stopping short of a deeper discussion in this direction. I will look for the most usual definitions and usages, without trying, however, to map all their meanings in the enormous literature that makes use of them.

I will first focus on the concepts of hazard, vulnerability, risk, threat and resilience. They will then be articulated with the concepts of adaptation, mitigation and precaution. Insofar as it seems quite well-established that current climate change is at least to a large extent anthropogenic, the mix between 'society' and 'nature' is particularly evident. Anthropocene and Capitalocene complete the bundle of categories analysed here, but only the first is present in the globally dominant lexicon. In 
addition, it should be noted from the outset that, if I initially use the concepts of 'society' and 'nature' in a conventional way, both require, in order to be properly treated, a more in-depth analysis. This will be done in a latter section, since the very existence of these two separate universes must be questioned, taking us to the modern limits of the theme. We will therefore start from more specific concepts and will move on to more general concepts in the course of the paper ${ }^{1}$. It connects and lends a strong inflection to the discussions on the environment, highlighting the effects of human intervention in the 'natural' world in all its complexity, a perspective that critical thinking, from Marx to Gorz, including the Frankfurt School, has insisted upon, even if productivism-oriented strands have long enjoyed prominence within Marxism and other socialist and/or developmentalist currents.

It is true that critical theory produced some assessments of climate change. Different strands, with distinct connections to critical theory traditions, focused on different issues. This includes discussions on justice (Parks \& Timmons, 2010), the Anthropocene (Angus, 2016) and the Capitalocene (Moore, 2014), the extension and radicalisation of the destructive aspects of the 'dialectic of the Enlightenment' (Görg, 2016) and 'emancipatory catastrophism' (Beck, 2016); on how Foucault's concept of 'governmentality' can be mobilised to tackle responses to climate change (Lövbrand et al., 2009) and how a non-anthropocentric ethics can be worked out from Adorno and Horkheimer's as well as Habermas' theories (Cooke, 2020); or on the very definitions of 'nature' and 'society' (Domingues, forthcoming). Yet, there is still much to be done. In particular, a broader conceptual account is still lacking.

It is true also that there is an abundant literature about 'regimes' - or 'governance' - of climate change, especially regarding the UN system and in the field literature of international relations. Here, within the aforementioned critical immanent approach, I want to connect it to an analysis of the climate change lexicon but also to political sociology. I shall thus link two issues - discourse and power - which are still not fully articulated in the available literature, with an emphasis on its problematic, albeit partial, depoliticszation. A further advance in terms of a critical theory approach should be thereby achieved.

\section{Hazard, Risk and Threat, Vulnerability and Resilience}

We may define a hazard - a potential danger - as any phenomenon potentially capable of causing harm, not only to the human species, but also to 'nature' in general (Blaikie et al., 1994). In that sense, a hazard may have, and often has, material and even natural characteristics. Moreover, this is how this concept is generally employed in disaster analysis in general. However, a potential danger can also derive

\footnotetext{
1 The concept of 'sustainable development', now somewhat out of fashion but appearing in UN/IPCC discussions and documents, could be included here as well, with its tense and unstable coupling. It was analysed in detail in Nobre \& Amazonas, 2002. See also, for very recent views, Neckel, 2020 and Adloff, 2020. 'Coping' is another term that, coming from the discipline of disasters, circulates in the analyses, mixed in general with adaptation.
} 
from society's intervention in nature, as it is partly shaped by human action. In this sense, when we talk about climate change, it is hardly possible to separate one thing from the other once we recognize anthropogenic elements among its causal mechanisms. Finally, a hazard can be thought of as eminently socio-human, although never dispensing, like anything in social life, a material element or basis. In any event, what constitutes a hazard in a social - or even natural - circumstance may not appear so in another case or may be greatly minimised. It is necessary to reconstruct the chain of causality, that is, the reasons why a potential danger presents itself and the preconditions in which the systems in question are found, which are articulated by specific causalities, in the short, medium, long and even very long term.

The conditions in which the system finds itself in the face of potential dangers may be called, as is usually done, vulnerability, which is often taken as something given, objectively (Adger, 2006; Brooks, 2003; Fussel, 2005; Ribot, 2014). On the other hand, it arises, in the definition I propose here, from the possible impact that a hazard may have on a human or natural community. It depends on its constitution and is the result of power relations, as well as of production and distribution, the level of knowledge about itself, political will, and so on. But it is necessary above all to ask who is vulnerable, how this happens, and how a collectivity is vulnerabilised. In other words, it is a matter of asking about its causes, whether more immediate or deeper. In addition, resources are produced and distributed to deal with vulnerability, including the chain of causality and the conditions that emerge from it. It may thus be said that, rather than raw data, vulnerability is also largely a social construction, one that is symbolically mediated and that includes its cognitive element. It rests on the interaction between agents, within which power plays a central role. In modernity, politics is crucial in this regard, yet material elements are also intrinsic to its constitution.

Risk may be defined as the intersection between a potential danger and a vulnerability that can be precisely or vaguely calculated (mathematically and even statistically), often implying conflicts (Beck, 1986, 2016; Hammer et al., 2019; Domingues, 2020 - where the concept of risk is discussed in much greater detail, including its double-bind: objective-natural and socially-constructed). That is, risk depends on the degree of vulnerability that any community presents. A risk may be thought of as deriving from purely natural causes, but may also be derived from a social construction, like hazards and vulnerability, thus depending on a definition that sets it apart from other possibilities (which would not, therefore, constitute a risk). It is in this confluence of materiality and social construction that risk is established. In turn, threat can be defined as a risk that has become a concrete reality. It is in concrete reality that hazard becomes effective, causing damage. This is, partly, more or less profound depending on the degree of vulnerability that any system shows.

Finally, resilience - a concept that appeared in engineering to define the ability to respond to a stressor - refers to how systems with varying degrees of vulnerability answer to an impact (Proag, 2014; Olsson et al., 2015). That is, it refers to whether, to which extent and how they withstand stress, resisting with greater or lesser damage and returning more or less quickly to their previous state - if they ever do - or even improving their performance. However, it is more proper to assume resilience, obviously, as a social construction, dependent upon power, relations of production 
and distribution, level of knowledge, political will, similarly to hazards, risks and vulnerabilities, as previously mentioned (Iwama et al., 2016).

The concrete definition and the specific evaluations of all these notions also depend on bias, conflicts and objectives of different agents. In order to clarify these notions, let us briefly look at a crucial recent example (see Domingues, 2020). The coronavirus/COVID-19 pandemic appeared as a hazard that comprised a risk that in turn depended on the vulnerability of the world population and that of each country, naturally and socially constituted. For this reason, although nobody knew which organism could generate infections on a global scale, the World Health Organization (WHO) called for preparation in the face of possible pandemics. As the virus spread uncontrollably, the coronavirus became a threat to national and worldwide populations. This happened to a great extent because the preparation for a pandemic was flawed and insufficient and also because the development and application of measures at the national level happened unevenly. Furthermore, most health systems were not fully prepared. In fact, health systems, together with other factors of different orders, today define the resilience of national and global societies in the face of the current pandemic. The global lack of preparation led to greater vulnerability, but this too was unevenly distributed. This unevenness was due to previous conditions, socially articulated by specific causalities, in the short, medium and very long term, including relations among countries, increasing or decreasing levels of resilience (Domingues, 2020, 2021).

It must be emphasised that a 'disaster' like the coronavirus/COVID-19 pandemic, although its causes may be largely impossible to control, unfolds from political decisions, both prior and subsequent to the event. It mobilises a wide range of social issues and conflicts, generating social conditions, in a broad sense, from which it and its impact evolve, hinging on previous social conditions - to begin with, economic and political, broadly conceived - that magnify or minimize it. The same is true in relation to all aspects of climate change, and even more so because it contains a high degree of anthropogenic causes. Politics and society in general are intrinsic to it, as are the solutions proposed to deal with it and the disruptions it will most certainly cause.

\section{Mitigation, Adaptation and Precaution}

Other fundamental concepts of the imaginary and the vast field of study and public policies that have been advanced in the face of climate change can only connect to these apparently more technical and neutral concepts. This is the case with the precautionary principle (Jonas, 1984), as well as with, more recently, mitigation and adaptation, which has a long trajectory, particularly in the field of disaster response (Giddens, 2009, chap. 7; Fuller, 2013; Pelling, 2011; Basset \& Fogleman, 2013). It is necessary to politicise them, recognising their roots in political economy, in the workings of political systems, in public policies and in the social and civilising options we make. Neither is neutral in formulation or application. It is possible to adapt to a risk or threat facing its effects. But it is perhaps possible to change the 
conditions under which these systems operate so that vulnerability decreases or is even defined quite differently.

If mitigation is usually defined as the reduction of the emission of greenhouse gases (GHG) - such as carbon dioxide, methane and others - in the atmosphere, in order to reduce its concentration or slow down its growth, as well as promoting the capture of carbon that would otherwise be released into it, an effort is being made to reduce risk - and reduce threat. If we speak of adaptation as the reduction of vulnerability in the face of climate change, that is, the disasters associated with it, the concept depends on reducing risks and threats ${ }^{2}$. This also concerns the increase of resilience, with the strengthening of those who suffer from conditions of vulnerability, with further opportunities possibly developing. How both are achieved, which agents, which costs, which causal relationships must be faced and changed, are political issues that cannot be replaced by neutral perspectives. They are never limited to technical issues, which may well serve conservative purposes. This implies that adaptation is done without profoundly changing the conditions of the systems that have to adapt. In other words, in this last perspective vulnerability is reduced and resilience is increased without changing the parameters under which the system operates. This is carried out without basically changing the conditions of its existence at the time of its exposure to potential dangers, risks and threats.

But deeper changes in the functioning conditions of these systems may imply deeper adaptation, which would in addition involve issues related to justice - to the arrangements through which they exist and are reproduced. Such approach contrasts, however, with dominant conceptions originating from the area of disaster engineering, which, despite criticisms, was basically absorbed by the IPPC. The latter imply 'adjustment' (without changing parameters) and possibly improved functioning, according to the 'stimulus-response' model. There are many varieties of adaptation, including its definition as prevention, tolerance or sharing of losses, change of use, activity or location, or restoration of a previous, anticipatory, autonomous, spontaneous or planned state, considered as given capacity or as future adaptability. However, greater contextualisation and transformative perspectives in general are excluded from the debate. ${ }^{3}$

Furthermore, although climate change seems beyond doubt, its causes and magnitude are difficult to ascertain (as sceptics of different hues argue, differently from outright deniers). $\mathrm{Tt}$ is thus inevitable to resort to the precautionary principle. It harbours in its core the concept of responsibility, in this case with an emphasis on collective responsibility, which includes but goes beyond a legal perspective (Domingues, 2006, chaps 9-11). The idea that the precautionary principle should be abandoned because everything - any action - implies risk (Giddens, 2009, pp. 57-61) seems to brush

\footnotetext{
2 It is also possible to include mitigation in adaptation and this, in turn, in the concept of vulnerability, as a mobilizable capacity in the face of a potential danger, risk or threat.

3 Basset and Fogelman (2013) propose a typology for the definitions of adaptation: of adjustment, which is fundamentally that of the IPCC and reaches, in terms of the greater number of mainstream papers they analyze), 70 percent of prevalence; the reformist, with 27 percent; and the transformative, with a mere 3 percent. They rely on Pelling (2011), who speaks of adaptation as resilience, transition and transformation.
} 
aside that which risks are selected and how they are faced depend directly on how they are evaluated and how the costs to mitigate and adapt to them are accounted for. There is no purely technical criterion to define such risks, since they are particularly concerned with varied, manifold social and natural collectivities. In any case, the general problem is clear: climate change - largely derived from hazard: the emission of GHG and their permanence in the atmosphere - stands as a risk and threat, implying vulnerabilities (collectivities turned vulnerable) and resilience (with the adaptations that allow and/or expand them), constituting a social, economic and politically determined problem. This is true regarding both its genesis and its results. In any case it would be better to prevent or mitigate than to remedy climate change or adapt to it. This of course entails controlling the emission of GHG.

Thus, if adaptation focuses on 'protecting society from nature' (actually from the effects of climate change that are to a large extent humanly and socially produced), mitigation is also projected, though not exclusively, as 'protecting nature from society' (Stehr \& Storch, 2005; see also Görg, 2010, pp. 349-52). Mitigation is, as such, a form of 'protection' of society itself, and it is not possible to oppose these two strategies in a dichotomous way, although their operating principles are somewhat different. Rather, they are complementary. Neither does betting on mitigation imply seeing 'nature' as untouched; on the contrary, it is our practical intertwining with it that calls us to responsibility, either for its protection or for the protection of 'society'.

\section{Anthropocene and Capitalocene, Nature and Society}

As already argued, it is widely accepted, if not unanimous in the field of climate change studies and policies, that climate change results, at least to a large extent, from human action. In general - and according to the UN and the IPCC - it has been developing since the middle of the eighteenth century, as a result of the Industrial Revolution, the use of fossil fuels and populational growth. Global warming, along with other phenomena such as the acidification of oceans and the mass extinction of species that is underway, evinces anthropogenic causality. The new geological era that is being ushered in, characterised in particular by global warming, can and must therefore be defined as the Anthropocene, a neologism originally invented by the Dutch chemist Paul Crutzen. The Anthropocene would refer, as its comprehensive formulation denotes, to humanity as a whole, at a certain stage in history - with industry, fossil fuels and populational growth, that is, the human impact on the 'earth-system'. But the question is not so simple (Chakrabarty, 2009). If, in fact, an important change can be found at that historic juncture, it would not be industrialisation alone - as in a Durkheimian formulation - and its magnification through the use of coal and oil that would bear responsibility for the phenomenon. Or rather, this industrialisation and use of fossil fuels would be the work and responsibility of the Western bourgeoisie, which benefited and benefits from it. The poor, the workers and the wretched of the earth would have nothing to do with it, or at least are subordinate to the designs and profits of this bourgeoisie. There would be not a generic Anthropocene, but rather a Capitalocene, in which the incessant impulse of capitalist 
accumulation would imply a continuous and indeed growing intervention in nature (or the simultaneous constitution of nature and society through capitalism, dialectically) (Moore, 2014; Svampa, 2019). Some authors, following Rosa Luxemburg, would even see nature (especially raw materials) as necessary for the accumulation of capital, as an external element, crucial for capital to maintain its profitability in the face of the increasing participation of 'dead labour' in its 'organic composition'. Still others (including Crutzen) may recognise capitalism, but prefer to stress the 'Great Acceleration' since the 1850s, with respect to economic and population growth. The former took place mainly in 'developed' ('OECD') countries, the latter in those economically weaker countries ('non-OECD') (Steffen et al., 2011, 2015). This should, of course, include the old countries of 'truly existing socialism' (while they existed, as a specific system of rule, authoritarian collectivism) with the importance of the 'BRICS' (state capitalist China ahead) now increasing.

There is no reason to disagree with this particularisation of the causal chain that leads to climate change today with reference to capitalism and the 'bourgeoisies' (and whatever succeeds them in property and management terms). But it is also reductive. If there is a drive for accumulation, if there is consumerism and if the rich and affluent in the West establish living standards that are adopted at an increasingly global scale, particularly in Asia, the process is more long term and engages the species as a whole. This spans the past, in its search for well-being and the domination of nature, as well as the present and perhaps the future, since this consumerist pattern of life has spread throughout the world, even if not in an absolute way. In any case, well-being is a demand of all human beings and will not cease to be pursued. Obviously, what well-being represents is open-ended and does not need to mirror the imaginary, desires and consumption practices that characterise the wealthiest people in the world. Furthermore, capitalism is not eternal: though we cannot be sure, it may be replaced by a system that involves less destruction, de facto sustainable development and growth that can be less intense and rely on other types of technology and interventions in nature (either of a more 'traditional' style - which, however, cannot give up science and technology -, or decidedly and proudly modern).

In any case, it is the human species that is involved in this long-term process, carried out according to different values and objectives, as well as through countless conflicts, often with no clear goal in sight and usually entailing far-reaching non-intended consequences. If it is necessary to pay attention to the differentiations and unities, both national and global, of humanity latitudinally (in terms of classes, races, ethnicities, genders, countries and regions), the same is true longitudinally (in the development of the human species, which eventually converged in modernity) (Domingues, forthcoming). Besides, if it is possible to radically transform the potentially highly destructive relationship between society and nature, the human species and its environment, nothing tells us that capitalism cannot use the environmental crisis, particularly climate change, to its own advantage and the accumulation process. If capitalism overcame problems that seemed insoluble, it could overcome this as well, mobilising it in its favour (Gorz, [1974] 2010). One can even imagine that capital is able to use the imbalance it generates in the 'metabolism' between 'society' and 'nature' to its favour (Marx, [1867] 1962). 
However, the IPCC remains oblivious to this, not to mention the UN more directly. It would not extrapolate the framework of social liberalism if they were to adopt a definition of Anthropocene with a slightly less technocratic bias, with some attention to social causes and effects. In other words, in addition to the poverty that international agencies regard as an issue to be remedied and managed, the UN and the IPCC are concerned with the 'poor' in the face of climate change (IPCC, 2014). Moreover, this is a concern even for much of the literature that supports critical elements in relation to the dominant discourses and confers the discussion a social and political character. The concepts discussed above are marked by this link, even when the most vulnerable are seen as rendered vulnerable by social relations and the issue of adaptation and resilience takes this into account, with demands for sensitivity and, with a specific approach for those who are, in principle, more fragile, equity (but not equality) in addressing the issue. The global and especially the more official discussion cannot go much further without there being a genuine politicisation of the concept in these frameworks. For our purposes here, it suffices to raise the question.

Finally, the distinction between 'society' and 'nature' lies at the basis of all discussions on climate change. It is a central element in the hegemonic, though at this stage hybrid, modern imaginary, with the objectification of the latter in what regards economics - which is crucial for capitalism - and politics - in which society is considered an at least partly purposeful agent vis-à-vis nature, which appears as only and always a patient. There are many criticisms of this perspective, but it is deeply rooted and only will be overcome with very long-term changes, leading to a new civilisation. Overcoming means truly moving towards another type of civilisation. In fact, just like climate change, the deepening of human intervention in nature - our capacity to affect it - presents itself as a very strong trend in the contemporary world. In what direction is the main issue. Will civilisation become more destructive or more friendly, will it advance in a more conservative, reconstructive or restorative way? Critical theory has not been able to present a truly alternative view. In any case, we need to bear in mind that this must be done through the immanent criticism of this civilisation, even if, taken ecumenically, other civilisational aspects, meanwhile already incorporated into modernity, may have a role to play in this adventure.

Apart from daydreams about communicating with nature as a subject or its romantic resurrection (as in the approaches of other Frankfurt School members, such as Marcuse), only Adorno (1980, 1966, pp. 193, 285) suggested a path that broke with the logocentrism of the unified and abstract conception of 'nature', pluralising it and the relationship that the human species maintains with it, beyond the idea of 'object' (Objekt). Adorno himself proposed this shift in the framework of negative dialectic, therefore without allowing itself to go much further. On the other hand, there is the danger that, with this pluralisation, the unitary focus of the environmental political struggle is lost. This is a question to be considered, however I shall not try to propose an answer here (Domingues, forthcoming). Regardless of how we cope with it, it is worth emphasising that in the lexicon of climate change the separation between 'society' and 'nature' is an imaginary foundation. They appear as fixed and apparently eternal concepts, organising modernity and everything we say about the world within its framework - at least until very recently. 


\section{Lexicon and Power}

In the literature on international relations, the concepts of 'regime' or 'governance' have been usually employed to frame agreements and policies at the global level. This includes international organisations, such as the UN and the IPCC regarding the climate, as well as national governments, non-governmental organisations (NGOs) and corporations (recalling here that business has a seat in the IPCC) (Keohane \& Victor, 2010; Chasek et al., 2017, pp. 20ff; Sprint \& Luterbacher, 2018). Much has been written on the complexity, complicated dynamic and fragmentation of this regime, among other issues. We may reach the conclusion that there is an irremediable schism between international agreements and policies on climate change (difficult to consolidate and dependent upon many negotiations, but always leading to partial results) and interests and values, as well as geopolitical competition and correlations of global forces. We may think, however, that, despite all problems and stalemates, the process has moved forward and can, and will surely, move further in the direction of seriously addressing the problems that beset us (Dahan, 2016). Yet it is important to bring out and stand against the 'depoliticisation' of the debate and, as this article has laid out, of the lexicon we have previously examined, which is indeed underpinned by political issues and choices, despite their apparent technicality (see for instance, for other, related issues, either encompassing or regarding the environment the following authors, though only the last cursorily deals with climate change: Petiteville, 2018; Maertens \& Parizet, 2017; Louis \& Maertens, 2021).

In the case of the UN climate change regime, monopolisation, recourse to expertise and neutrality may be seen as the outstanding elements of this process of depoliticisation. The IPCC excels on the recourse to expertise, though drawing upon the other two as well. What it does may well be dubbed 'consensual knowledge' - 'normal science', mainstream, in Kuhnian terms, therefore pushing out divergent views, whether sceptical or catastrophist (Shackley, 1997; Urry, 2011, chaps. 1-3, 6-7). We need not agree with either of these other two perspectives to acknowledge how the IPCC's mainstream, more gradualist conceptions, are defended. In the end they all include some degree of uncertainty, due to the character of the research they carry out (especially in what regards climate modelling in open systems, with complicated mathematical formulations and unknown variables in the mainstream view), though it would be incorrect not to recognise the depth of the IPCC's research and analyses.

Let me stress that I do not claim that the whole debate is totally depoliticised, despite the attempt to establish a framework which would subsume all other issues as relatively unimportant or subordinated to it (Swyngedouw, 2010). On the contrary, even the UN system falls short of successfully completing those depoliticising manoeuvres. One way or another, the global society is quite aware of the issue and has been grappling with different alternatives. Urry (2011, pp. 88-94) was therefore correct when he eschewed the general thesis of depoliticisation through climate change discourse. Social movements, NGOs, the press, scientists and the common citizenry have been part and parcel of a public debate on the topic. Yet those operations carry on and aim to subtract the inevitable and 
absolutely central political elements of the issue, a procedure that on the other hand heavily influences the discussion.

It is therefore necessary to further explore the underpinnings of that process of partial depoliticisation and advance through its social constitution, including its conflicting aspects. This has already been partly done with the political demand that those who globally polluted and pollute pay more for solutions (in connection with the polluter pays justice principle - Okereke \& Coventry, 2016). Nevertheless, this is evidently only one facet of the issue (see for example Jamieson, 2005). This should take us in particular beyond goodwill, beyond social liberalism and the 'green' strategies of large international corporations. These agents already use this vocabulary widely, subordinating it to their own interests and imperatives (Wright \& Nyberg, 2015).

A further consideration must be added regarding the role of power in the conformation of the climate change lexicon, especially in what concerns the role of the IPCC and the UN system more generally. As we have seen, some of these categories have a long history, emerging as part and parcel of modernity ('society' and 'nature'). They can be therefore easily connected to the emergence of the bourgeoisie, although the development of such imaginary harks back to even prior periods (ancient Israel, Medieval 'Europe'). The more specific categories surrounding climate change are of course of more recent elaboration. They reflect the power dynamics of the UN system and its global connections and roles. Which are they?

We can point here to an 'epistemic community' (Haas, 1992) as responsible for their elaboration and shifts of meaning. It is however correct too to see them as partly dependent (as 'agents' of 'principals') upon the nation-states that created, fund and directly or rather more indirectly steer the organisation in which they are nested, even though they also have their own agendas and dynamics, as well as a discursive, hermeneutical horizon (Barnett \& Finnemore, 2004, pp. 4, 22-23). The collaboration with big corporations must also be considered, including the 'social compact' in which they participate within the UN (Murphy, 2018), along with some impact of societal agents on the latter's official organs of representation and administration. This happens within what may be called the 'global societal political system' and the 'global para-state political system' (Domingues, 2019, chap. 9), of which the UN and increasingly the IPCC are crucial components. State delegates in fact have the strongest voice in the review of the IPCC's reports prior to their release (Shackley, 1997), although NGOs and industry also have a place in shaping in these meetings, and regardless of the greater relevance citizens and global public opinion have achieved vis-à-vis climate change (Tosun \& Schoenefeld, 2017). If the representatives of nation-states become really annoyed by the positions of some of these bodies, they may exert veto power, stop funding or simply exit them, as the United States under president Donald Trump, for instance, did with respect to the Kyoto protocol. In addition, the links between states and business, as well as with other societal agents, must always be borne in mind, within their national political systems and by other means (Domingues, 2019, chap. 4), which affect their positioning visà-vis the diverse UN programmes and agencies.

Thus, the IPCC inevitably stands at the shifting 'boundary' between science and politics (Beck \& Mahony, 2018). It has to do 'work' on the issue. In practice, it 
operates within a set of constraints that define its leeway when it comes to assessments, let alone policies. At the same time the IPCC has to be careful so as to maintain its credibility as a scientific body.

In other words, we must not lose sight of either the links or the relative autonomy of the UN system regarding states and societal agents when we discuss climate change policies and the lexicon entangled with them. Moreover, a more general idea of 'hegemony', in a Gramscian sense, must be brought to bear, establishing how much leeway there is for the emergence of possibilities of the discourse and police of climate change, as Cox (1983) more generally observed a few decades ago. This specifically involves the reproduction of the traditionally modern political dimension and of capitalism, with its relentless accumulation drive, which the IPCC and the epistemic community it organises has never questioned (Foster, 2019). Actually, this would be beyond its mandate within the UN system.

\section{Conclusion}

This paper has addressed the lexicon of climate change with the perspective of a critique that moves through the concepts of mainstream formulations and how they are embedded in social relations, stressing power, as well as specific interests, at the global level. A critical engagement with the topic has been limited, however, to more specific concepts, while the institutional aspect has not been systematically addressed. I have tried to remedy this here.

The boundary between politics and science is complicated with respect to climate change, since scientists can hardly please both camps, the former being particularly fraught with tensions. A supposed lack of transparency of the IPCC has also been at stake (Carr \& Rubenstein, 2010). Besides, criticism by mainstream scientists and media has been mostly directed to sceptics and especially deniers, who are in fact often connected to the oil, coal and old and very pollutant enterprises and sectors, as well as financed by extremely conservative foundations in the United States (Brulle, 2014). Nevertheless, we must also bear in mind that the lexicon and surely the policies which are globally hegemonic today find their limits in what is acceptable in the UN system and for those forces that underpin it, namely, capitalist corporations, the global financial system and nation-states. There is no scientific neutrality here; politics is inescapable, stemming from how power, influence and overall relations of force are played out.

As mentioned above, IPCC reports have more recently included the social sciences and some level of recognition of political issues, although, for instance, its political economy relies heavily on conservative neoclassical economics ${ }^{4}$. However, this shift remains very limited and is mostly acritical of actual social arrangements. While directly connected to the power and interests of nation-states and

\footnotetext{
${ }^{4}$ Everything that has been said thus far also applies to the famous Stern Review (Stern, 2007), with its concern with mitigation and adaptation, the 'poor' and the concealing of conflicts, as well as the mere suggestion of 'building support' for those two perspectives. Neoclassical economics (without an iota of political economy) and technocratic perspective are its pillars.
} 
corporations, this also encompasses the dominant epistemic community of climate change. This reveals a truly global hegemony, though there are other strands which entertain a more critical perspective of such phenomena. A critique of how the world is arranged and how it impacts the 'earth-system' and its climate can be carried out either through the concept of Capitalocene or even within the more general concept of Anthropocene, since the latter contains, in principle, greater critical potential, especially if taken beyond its rather limited social analysis (more so, in my view, than the not so rigorous and climate change-oriented concept of Capitalocene) (Angus, 2016). But in order to achieve this it would have to dig deeper in the social processes that underpin climate change. In any case, altering the lexicon also implies changing power relations and the development of social struggles and mobiliszation in the direction of a more critical and transformative perspective.

Is it possible to face the issue of climate with perspectives that do not clash with the dominant projects and vocabularies - the lexicon we have examined here and its derivations? I believe that this is possible only in part. Such perspectives can play an effective role, but may not lead to more profound changes in several aspects. After all, nation-states and capitalism, in addition to promoting social liberal alternatives or even a green social-democratic New Deal, can provide solutions, at least partial ones, to the environmental crisis and to climate change. I have attempted here, quite preliminarily, to start looking at how these polysemic notions or concepts are structured, locating their power-related underpinnings. I have criticised them and then developed how one could think positively, beyond these perspectives, without illusions of immediate radical civilisational changes, but aiming at them in the long run, albeit more implicitly.

It would make no sense to expect the world to change completely before proposing theoretical elaborations. Perhaps a path for critical theory opens up regarding the enormous literature on climate change. An immanent approach is a starting point, but we need not stop at that. It is not impossible to articulate such a demarche to deeper changes and move towards a more radical transformation of contemporary societies, although climate change and its emergency treatment are linked above all to strategies to mitigate GHG emissions and adapt society to it (Parenti, 2013). The task that finally begins is how to articulate these two time-frames, the immediate and the long term, without becoming either paralysed or simply embracing restrained change.

Funding I thank my colleagues at the Interdisciplinary Observatory of Climate Change of Rio de Janeiro State University, particularly Carlos Milani, for their comments on this paper. I also thank Sérgio Costa and Wolfgang Knöbl as well as Monica Herz and Fabricio Mello for comments and bibliographic indications. The research was funded by the Alexander von Humboldt Foundation (Anneliese Maier Forschung Preis - 2018/2023), CNPq (Brazil) and Faperj (Rio de Janeiro, Brazil).

\section{References}

Adloff, F. (2020). Vom richtigen Leben im falschen. Postwachstum, radikale Imaginaries und reale Utopie. Mittelweg, 36(29), 3-32. 
Adorno, T. W. ([1966] 1980). Negative Dialektik. Frankfurt am Main: Suhrkamp.

Adger, W. N. (2006). Vulnerability. Global Environmental Change, 16, 268-281.

Angus, I. (2016). Facing the Anthropocene: Fossil Capitalism and the Crisis of the Earth-System. New York: Monthly Review.

Barnett, M., \& Finnemore, M. (2004). Rules for the World: International Organizations in Global Politics. Ithaca, NY and London: Cornell University Press.

Basset, T. J. and Fogelman, C. (2013). Déjà vu or something new? The adaptation concept in the climate change literature. Geoforum (0016-7185/\$), 42-53.

Beck, S., \& Mahony, M. (2018). The IPCC and the new map of science and politics. Wires Climate Change, 9(e547), 1-16.

Beck, U. (1986). Risikogesellschaft. Auf dem Weg eine andere Moderne. Frankfurt am Main: Suhrkamp.

Beck, U. (2016). The Metamorphosis of the World. Cambridge: Polity.

Blaikie, P. et al. (1994). At Risk: Natural Hazards, People's Vulnerability, and Disasters. London: Routledge.

Brooks, N. (2003). Vulnerability, risk and adaptation: A conceptual framework. Working Paper 38, Tyndall Centre for Climate Change, 1-16.

Brulle, R. J. (2014). Institutionalizing delay: Foundation funding and the creation of US climate change counter-movement organizations. Climate Change, 22, 681-694.

Brulle, R. J. \& Dunlap, R. E. (2015). Sociology and the global climate change: Introduction. In Brulle, R. J. \& Dunlap, R. E. (eds), Climate Change and Society: Sociological Perspectives. New York: Oxford University Press.

Carr, M.-E., \& Rubenstein, M. (2010). Challenges to authority: Understanding critiques of the Intergovernmental Panel on Climate Change. Union Seminary Quarterly Review, 63, 42-66.

Chakrabarty, D. (2009). The climate of history: Four theses. Critical Inquiry, 35, 197-222.

Cooke, M. (2020). Ethics and politics in the Anthropocene. Philosophy and Social Criticism, 46, 1167-1181.

Cox, R. W. (1983). Gramsci, hegemony and International Relations: An essay on method. Millennium: Journal of International Studies, 12, 162-75.

Chasek, P. S., Downie, D. L. \& Brown, J. W. (2017). Global Environmental Politics: Dilemmas in World Politics. London: Routledge, 7th edition.

Dahan, A. (2016). La gouvernance du climat: Entre climatisation du monde et schisme de réalité. L'homme et la société, 199, 1-8.

Domingues, J. M. (2006). Modernity Reconstructed. Cardiff: University of Wales Press.

Domingues, J. M. (2019). Critical Theory and Political Modernity. New York: Palgrave Macmillan.

Domingues, J. M. (2020).From global risk to global threat: State capabilities and modernity in times of coronavirus. Current Sociology, online first, 1-18.

Domingues, J. M. (2021). Coronavirus and social change, in: Bringel, B. \& Pleyers, G. (eds), Social Movements and Politics in a Global Pandemic. Bristol: Policy Press - Bristol University Press.

Domingues, J. M. (forthcoming). The political dimension of modernity and the unsurpassable exteriority of 'nature'. International Journal of Social Imaginaries, 1.

Foster, J. B. (2019). On fire this time. Monthly Review, 71, 1-17.

Fuller, S. (2013). Beyond the precautionary principle. The Guardian, July 7 (https://www.theguardian. com/science/political-science/2013/jul/10/beyond-precautionary-principle).

Fussel, H.-M. (2005). Vulnerability in climate change research: A comprehensive conceptual framework. University of California International and Area Studies, Paper, 6, 1-34.

Giddens, A. (2009). The Politics of Climate Change. Cambridge: Polity.

Görg, C. (2010). Vom Klimaschutz zur Anpassung: gesellschaftliche Naturvehältnisse im Klimawandel, in: Voss, M. (ed.), Der Klimawandel. Sozialwissenschaftliche Perspektiven. Wiesbaden: VS.

Görg, C. (2016). Zwischen Tagesgeschichte und Erdgeschichte. Gaia, 25, 9-13.

Gorz, A. ([1974] 2010). Leur ecologie et la notre. Le Monde diplomatique, April: 28.

Haas, P. M. (1992). Introduction: Epistemic communities and international policy coordination. International Organization, 46, 1-35.

Hammer, C. C., Brainard, J., Innes, A. \& Hunter, P. R. (2019). (Re-)conceptualizing vulnerability as a part of risk in global health emergency response: Updating the pressure and release model for global health emergencies. Emerging Themes in Epidemiology, 16(1). 
IPCC. (2014). Climate Change 2014: Synthesis Report: Contribution of Working Groups I, II and III to the Fifth Assessment Report of the Intergovernmental Panel on Climate Change. Geneva: IPCC (including 'Anex II: Glossary').

Iwama, A. Y. et al. (2016). Risk, vulnerability and adaptation to climate change: An interdisciplinary approach. Ambiente \& Sociedade, XIX, 93-116.

Jamieson, D. (2005). Adaptation, mitigation, and justice, in: Sinnott-Armstrong, W. \& Howarth, R. (eds), Perspectives on Climate Change: Science, Economics, Politics, Ethics (Advances in the Economics of Environmental Resources, Vol. 5). Bingley: Emerald Group Publishing Limited.

Jonas, H. (1984). Das Prinzip Verantwortung. Versuch einer Ethik für die technologische Zivilization. Frankfurt am Main: Suhrkamp.

Keohane, R. \& Victor, D. (2010). The regime complex for climate change. The Harvard Project on International Climate Agreements, Discussion Paper 10-33.

Louis, M. \& Maertens, L. (2021). Why International Organizations Hate Politics: Depoliticizing the World. London: Routledge.

Lövebrand, E., Stripple, J., \& Wiman, B. (2009). Earth System governmentality: Reflections on the Anthropocene. Global Environmental Change, 19, 7-13.

Maertens, L., \& Parizet, R. (2017). 'On ne fait pas de politique': Les practiques de depoliticization au PNUD et au PNUE. Critique Internationale, 76, 41-60.

Marx, K. ([1867] 1962). Das Kapital. Kritik der politischen Ökonomie, vol. 1, in: Marx, K. \& Engels, F., Werke, vol. 23. Berlin: Dietz.

Moore, J. W. (2014). Capitalism in the Web of Life: Ecology and the Accumulation of Capital. London: Verso.

Murphy, C. N. (2018). Private sector. In Weiss, T. G. \& Daws, S. (eds), The Oxford Handbook on the United Nations. Oxford: Oxford University Press, 2nd edition.

Neckel, S. (2020). Der Streit um die Lebensführung. Nachhaltigkei Als Sozialer Konflikt. Mittelweg, 36(29), 82-100.

Nobre, M. \& Amazonas, M. C. (2002). Desenvolvimento sustentável: a institucionalização de um conceito. Brasília, IBAMA.

Olsson, L., Jerneck, A., Thoren, H., Persson, J. \& O'Byrne, D. (2015). Why resilience is unappealing to social science: Theoretical and empirical investigations of the scientific use of resilience. Science Advances, 1 (e1400217).

Okereke, C., \& Coventry, P. (2016). Climate and the international regime: Before, during, and after Paris. Wires Climate Change, 7, 834-851.

Parenti, C. (2013). A radical approach to climate change. Dissent, Summer (https://www.dissentmagazine. org/article/a-radical-approach-to-the-climate-crisis).

Parks, B. C., \& Roberts, J. T. (2010). Climate change, social theory and justice. Theory, Culture \& Society, 27, 134-166.

Pelling, M. (2011). Adaptation to Climate Change: From Resilience to Transformation. London: Routledge.

Petiteville, F. (2018). International Organizations beyond depoliticized governance. Globalizations, 15, 301-313.

Proag, V. (2014). The concept of vulnerability and resilience. Procedia Economics and Finance, 18, $9-16$.

Ribot, J. (2014). Cause and response: Vulnerability and climate in the Anthropocene. Journal of Peasant Studies, 41, 667-705.

Rodríguez Ortiz, M. E. (2014). O combate a pobreza em uma era global: o Banco Mundial, Brasil, Índia e outros casos. PhD Thesis in Sociology, IESP-UERJ.

Shackley, S. (1997). The Intergovernmental Panel on Climate Change: Consensual knowledge and global politics. Global Environmental Change, 7, 77-79.

Sprint, D., \& Luterbacher, U. (eds.). (2018). Global Climate Policy: Actors, Concepts and Enduring Challenges. Cambridge, MA: MIT Press.

Steffen, W., Grinewald, J., Crutzen, P., \& Mcneill, J. (2011). The Anthropocene: Conceptual and historical perspectives. Philosophical Transactions of the Royal Society, 369, 842-867.

Steffen, W., Broadgate, W., Deutsch, L., Gaffney, O., \& Ludwig, C. (2015). The trajectory of the Anthropocene: The Great Acceleration. The Anthropocene Review, 2, 81-98.

Stehr, N., \& Storch, H. (2005). Introduction to papers on mitigation and adaptation strategies: Protecting nature from society or protecting society from nature? Environmental Science \& Policy, 8, 537-540. 
Stern, N. (2007). The Economics of Climate Change: The Stern Review. Cambridge: Cambridge University Press.

Svampa, M. (2019). El antropoceno como diagnóstico y paradigma. Lecturas globales desde el sur. Utopia y praxis latinoamericana, 24(84), 33-54.

Swyngedouw, E. (2010). Apocalypse forever? Post-political populism and the spectre of climate change. Theory, Culture \& Society, 27, 213-232.

Tosun, J., \& Schoenefeld, J. J. (2017). Collective climate action and networked climate governance. Wires Climate Change, 8(e440), 1-17.

UN/ISDR - United Nations Inter-Agency Secretariat of the International Strategy for Disaster Reduction. (2004). Living with Risk: A Global Review of Disaster Reduction Initiatives (Vol. 1). Geneva: United Nations.

Urry, J. (2011). Climate Change \& Society. Cambridge: Polity.

Wright, C., \& Nyberg, D. (2015). Climate Change, Capitalism, and Corporations: Processes of Creative Self-Destruction. Cambridge: Cambridge University Press.

Publisher's Note Springer Nature remains neutral with regard to jurisdictional claims in published maps and institutional affiliations. 